Theatre Research in Canada

Recherches théâtrales au Canada

Poll, Melissa, Robert Lepage's Scenographic Dramaturgy: The Aesthetic Signature at Work. London: Palgrave Macmillan, 2018, 199 pp.

\title{
Piet Defraeye
}

Volume 41, numéro 1, 2020

URI : https://id.erudit.org/iderudit/1071762ar

DOI : https://doi.org/10.3138/tric.41.1.160

Aller au sommaire du numéro

\section{Éditeur(s)}

Graduate Centre for the Study of Drama, University of Toronto

\section{ISSN}

1196-1198 (imprimé)

1913-9101 (numérique)

Découvrir la revue

Citer ce compte rendu

Defraeye, P. (2020). Compte rendu de [Poll, Melissa, Robert Lepage's

Scenographic Dramaturgy: The Aesthetic Signature at Work. London: Palgrave

Macmillan, 2018, 199 pp.] Theatre Research in Canada / Recherches théatrales

au Canada, 41(1), 160-162. https://doi.org/10.3138/tric.41.1.160 d'utilisation que vous pouvez consulter en ligne.

https://apropos.erudit.org/fr/usagers/politique-dutilisation/ 


\title{
POLL, MELISSA
}

Robert Lepage's Scenographic Dramaturgy: The Aesthetic Signature at Work.

\author{
London: Palgrave Macmillan, 2018, 199 pp.
}

PIET DEFRAEYE

Robert Lepage's Scenographic Dramaturgy by Melissa Poll provides a significant contribution to Lepage scholarship, as it focuses on the visual aspects of Lepage's productions, particularly his operatic work, which so far has been under-researched. Her study is based on Ex Machina materials, extensive use of production reviews, her attendance at rehearsals and performances, interviews with Lepage, existing Lepage scholarship, and videographic material. The first chapter introduces some key critical concepts: "historical-spatial mapping," "architectonic scenography," and Poll's approach of Lepage's performance as "kinetic text." Four subsequent chapters offer analyses of specific productions, with the first two focusing on opera work.

While Lepage's art is often mystified as the intuitive product of a genius artist, Poll starts off with charting some influences, principles, and structure in Lepage's creative process, including his penchant for physicalized acting through Lecocq-trained mentors like Marc Doré and Alain Knapp. His directorial involvement with Jacques Lessard's Théâtre Repère introduced Lepage to Anna Halprin's RSVP cycles. The subsequent founding of his own Ex Machina laboratory (1994) has given him a unique platform to experiment with dramaturgical strategies that go well beyond textual analysis. Poll proposes the critical concept of historical-spatial mapping, as "the backbone of Lepage's scenographic dramaturgy" (3). This mapping refers to specific socio-cultural circumstances of historical spaces that are articulated in Lepage's architectonic scenography.

The latter concept is repeatedly, though unconvincingly, foregrounded as a lineage marker between Lepage and Edward Gordon Craig; Poll argues parallel visualization strategies between the two when it comes to Wagner operas. Similarly, calling Lepage's scenography "Appian" gives food for thought, however the suggestion that Adolphe "Appia's evocative sketches and theories for the Ring can be seen in Ex Machina's production" (97) seems academic. Poll situates Lepage's performance aesthetic within a contemporary practice that prioritizes spectacle and visuality. She briefly flags Ariane Mnouchkine, Julie Taymor, Simon McBurney, Benedict Andrews, the Wooster Group, and Robert Wilson as trendsetters for this "signature visual approach" (24), though other important contemporary performance auteurs like Bondy, Castellucci, Fabre, Perceval, Sellars, Thalheimer, Van Hove-each of which straddle opera (including Wagner) as well as auteur-creation - are largely absent from the discussion of dramaturgical context.

A third central critical concept in Poll's Lepage exegesis, the kinetic text, hones in on the function of the moving body, in concert with the moving set/space. She accredits this mostly to the contributions of Lepage's collaborators, often ignored in scholarship, and it is one of 
the volume's merits that these collaborators are named and foregrounded for a number of productions, particularly in his operatic and musical work.

The four subsequent chapters offer a close-reading/performance analysis of several Lepage productions. Two of these case-studies focus on operatic work. A third analyzes Lepage's intercultural collaborative process of La Tempête (2OII). The study concludes with Lepage's auto-adaptations The Blue Dragon and Needles and Opium. Starting with The Nightingale and Other Stories, Ex Machina's 2009 adaptation of Stravinsky's Le Rossignol (with some shorter fables added), Poll looks briefly into the creative genesis and performance history of the original work, which provides fascinating reading. Moving on to Lepage's multi-layered $c h i^{-}$ noiserie, she sees it as a promising departure from his earlier "undifferentiated, singular East" (6I) approach in productions like The Dragon's Trilogy (1985). The Nightingale, according to Poll (and echoing Lepage himself), demonstrates "a new sensitivity to diverse cultural contexts and history" (62). This more complex East is composed through ample visual interventions, including costumes, puppetry, scenographic effects, acrobatics, thus creating a multi-layered feuilletage of a historically refractured narration.

With its sixteen-million dollar budget, its computerized forty-five ton moving set, and a gestation period of over six years, Ex-Machina/Metropolitan Opera's sequential production of the Wagner's Nibelungen cycle (2OIO-2OI2) remains Lepage's most ambitious project. Poll's brief production history of Wagner's cycle foregrounds the potential influence of Adolph Appia; while Appia certainly deserves a place in this history and his inclusion provides useful context, naming Lepage's music-made-visual aesthetic a realization of Appian scenography reads as farfetched. More interesting is Poll's discovery that Lepage "spent sixteen hours rapt by the television transmission of [Patrice] Chéreau's centenary [1976] production" (93). The historical layering here, through for instance François St-Aubin's (pseudo) historical costuming, seems a nod to Chéreau's mise en scène, as is the politically informed choice of African-American baritone Eric Owens in the controversial role of Alberich so as to confront the implied anti-semitism of the role. Curiously, Poll does not reference the Deutsche Grammophon 20I2 DVD set of the Nibelungen cycle, which is not only a rare, but at the same time an exhaustive publicly available archive of Lepage stagecraft.

Lepage's Shakespeare creations are legendary, but the 2009 collaboration on The Tempest with the Huron-Wendat Nation (Wendake, QC) has received little critical focus. Poll weights her words carefully when she credits the production with potential to resist the tendency of Western theatre to sample and reduce Indigenous signature to a mere tokenism. While the outcome was an eclectic mélange of Shakespeare text, westernized Indigenous dance, Québécois chanson, nature-inspired mythology, and physicalized acting, Poll sees La Tempête as an important step for Ex Machina "towards empowering its collaborators and lessening power imbalances" (I44). (Poll's 2018 study is not able to engage with recent controversies around $S L \bar{A} V$, the cancelled 2018 Montreal International Jazz Festival production, due to publication timelines.)

In the final chapter, Poll looks at Lepage's auto-adaptations, notably The Blue Dragon (2008), a re-adaptation of The Dragon's Trilogy (1985, re-created in 2003). While the original suffered from a deeply embedded Orientalism, Poll calls the most recent re-adaptation "uniquely successful in offering a vastly revised and nuanced representation of China" (I59). This is achieved through successful historical-mapping, a result of inclusive collaborations with 
artists like Singapore-born choreographer and dancer Tai Wei Foo, and Québécois graphic novel artist Fred Jourdain. Nevertheless, Poll points out that it remains troubling that the only authors credited are Robert Lepage and his original co-devisor Marie Michaud. Poll concludes the chapter with a short look at the 2013 inter-medial auto-adaption of the I99I version of Needles and Opium, with the introduction of African-Canadian acrobat-dancer Wellesley Robertson III replacing a mere silhouette moment in the original. Strangely, while hammering the need to acknowledge the contributions of Lepage's collaborators, Poll herself leaves the Gréco actress in her analysis nameless, "played silently by an Ex Machina technician" (I7I). On the other hand, her study does include many of Lepage's creative collaborators on scores of productions. On top of the ones already mentioned, she includes designers like Mara Gottler (costumes), Étienne Boucher (light), Carl Fillion (set), Noam Markus and Jean-François Faber (acrobatics), Michael Curry (puppets), and Pedro Pires (video) in her performance analyses.

While the $\mathrm{PhD}$ dissertation regime is often noticeable, particularly in some of the tangential extrapolations, the book brings together tons of background information on the Lepage machine. Its performance analyses are carefully rendered. This is an important contribution to Canadian theatre scholarship.

\section{DUMAS, OLIVIER \\ La scène québécoise au féminin, 12 coups de théâtre 1974-1988. \\ Lachine, PQ: Éditions de la Pleine Lune, 2018, 240 pp.}

LOUISE FORSYTH

Olivier Dumas nous offre dans ce recueil d'entrevues la première vue d'ensemble des origines du théâtre québécois au féminin. ${ }^{\mathrm{I}}$ Les nombreuses manifestations de cette approche théâtrale féministe audacieuse ont émergé au cours des années I970 et I980, années effervescentes sur les scènes de Montréal, de Québec, et dans d'autres villes du Québec. Ce recueil de Dumas, qui fait entendre des réflexions et des souvenirs de certaines qui ont donné naissance collectivement à ces manifestations innovatrices, est une mine précieuse de témoignages mettant en lumière des émotions et les idées personnelles et collectives relevant de cette période où la parole et le jeu des femmes ont pris leur place sur les scènes des villes. Les questions réfléchies et bien informées posées par Dumas aux artistes indiquent qu'il s'est penché sur des aspects matériels de la pratique théâtrale adoptés par ces femmes passionnées. Le nom de quelques-unes de ces artistes est connu, mais celui de la majorité reste sans reconnaissance, leurs spectacles rarement reconnus, ni par les historiens du théâtre ni par la critique journalistique et savante d'hier et d'aujourd'hui. La persévérance de ces artistes dévouées à la création au féminin était remarquable. Elles ne cessaient de se battre contre tous les obstacles socio-culturels, professionnels, concrets, financiers et idéologiques qu'elles rencontraient. 